\title{
TEACHER'S STRATEGIES AND CLASSROOM MANAGEMENT TECHNIQUES IN TEACHING ENGLISH AT SMP INKLUSI TPA JEMBER
}

\author{
Citra Nostalgianti \\ IKIP PGRI JEMBER \\ prystiananta@gmail.com \\ Submit, 17-07-2020 Accepted, 22-12-2020 Publish, 29-12-2020
}

\begin{abstract}
The research aims at explaining the teacher's strategies and classroom management techniques applied in teaching English to mental retardation students at SMP Inklusi TPA Jember. This is a descriptive qualitative research. The subject of the research was an English teacher at SMP Inklusi TPA Jember. The data were collected through a non-participant observation and interview. The data were analyzed through identification, classification, data reduction, and description. The findings were: 1) the teacherused three kinds of strategies, i.e. imitation and modeling strategy, demonstration strategy, and active strategy with imitation and modeling strategy as the most used; 2) from 7 classroom management techniques listed by Sarosdy, Bencze, Poor and Vadnay (2016), there were only 5 techniques applied by the teacher including showing respect for students, showing professionalism, applying class techniques, applying positive attitude of teacher's role and knowing the students.
\end{abstract}

Keywords: Mental Retardation, Teachers Strategies, Classroom Management, Teaching Disable

\section{INTRODUCTION}

Teaching is a process which covers all of aspects of learners with no exception. Since human as learners may come from different background, teachers have to adjust their ways coping in teaching and learning. They should figure out the appropriate plans, method, evaluation based on the learners' needs and the objectives they wish to reach.

In teaching language, there are some important matters to consider such as the language, methods of learning, participants and classroom management in making teaching and learning process successful (Sarosdy, Bencze, Poor and Vadnay, 2006). Both teachers and learners as the primary participants in the activity, they have their own right and duties that have to be followed. The twoways communication is important to run the class efficiently.

However, teachers may also take into consideration the special type of learners such as learners with special needs. This type of learners requires the 
special skill teachers', too. Parsons et. el. (2001: 128) states that mental retardation students may show attention problem. They often pay attention to wrong things or have difficulty allocating their attention properly. And they also have difficulty to remember, especially with regard to those tasks that require complicated or deeper levels of processing, compared to their nondisabled peers. In society, mental retardation students have problems such as making trouble with friends and tending to have poor self concept.

Furthermore, Robertingall (in Rochyadi: 2005) conducted a researchonthe language skillsto mental retardation childrenusing theITPA (Illinois Test of Psycholinguistic Ability). It indicatedthat mental retardation children got difficulties in language acquisition, mastering grammatical and using a compound sentences. It means that mental retardation students have many problems in language. Children who are mentally retarded reach developmental milestones significantly later than expected (Onyekuru and Njoku, 2012).

In addition, Parsons et. el. (2001) states that mental retardation students may show attention problem. They often pay attention to wrong things or have difficulty allocating their attention properly. And they also have difficulty to remember, especially with regard to those tasks that require complicated or deeper levels of processing, compared to their nondisabled peers. In society, mental retardation students have problems such as making trouble with friends and tending to have poor self concept. Therefore, teaching strategy as well as the classroom management techniques in English subject for them is different from the regular ones.

Teaching strategy applied for students with special needs is focused on the way how to maximize the use of body movement and perception like visual and hearing. According to Parsons (2001), early elementary education for mental retardation focuses on teaching students readiness skill by including attention from the teacher. The teachers use auditory and visual stimuli and follow direction. Santrock (2008:) states that the teachers should be convinced to give concrete example of concept like making clear and simple instructional and oneon-one instructional the children receives.

In the previous research, Hsu and Lin (2006) the result shows that TPR on listening comprehension gave the immediate effects, two student learned the expressing abilities of English functional vocabulary immediately through TPR while one student did not, TPR on listening comprehension gave the maintaining effects and expressing abilities, it is recommended that blends and words with letter " $r$ " and sentences that are complex or similar should not be taught at first for the students, and students' motivation and interests in learning English were enhanced through TPR. 
Other observation by some researchers described some common teaching methods used in regular class which applied in inclusion class such as Grammar Translation Method, Silent Way, Direct Method, Question-Answer, Explanation and Discussion (Artiyah, 2016; Amalia, 2014). The facts show that teachers in some schools still not figuring out and considering some essential aspects to teach those special students. They mostly use conventional methods to teach English in inclusion class. The research may lead a misleading since they did not explain in detail whether the methods applied with special treatments. Another method applied by a researcher is Audio-Visual learning which involved technology (Resti, 2017). It sounds right and interesting. However, this research did not provide information that the method must be accompanied with the more suitable techniques as the valuable suggestion.

Moreover, teaching methods are not the only things to reach the teaching objective in inclusion class. Barbra \& Joyline (2014) revealed some perception regard with lack of expertise and inadequate resources in teaching. Teachers had scanty knowledge in this field. In fact, the teachers in this field require more knowledge to handle the special students including building positive attitudes as well as improving skill and knowledge. According to Gnanaguruvammal (2010), the higher education that teachers had the more favorable they may be. It supports the finding in this research that the attention on the classroom management deal with teachers' attitude in the classroom is beneficial to present.

The application of teachers' strategies is as important as the classroom management technique mastered by the teachers as the central knowledge and instructor. As explained previously, the special students with the special needs require special treatment from the teacher. The techniques in maintaining the discipline and well-organized teaching and learning process have to be applied well to reach the objectives. The techniques include showing respect for students, defining behavior boundaries, behavior modification, professionalism, class techniques, teacher's role, and knowing the students (Sarosdy, et.al, 2006).This concern will make a teacher has a better understanding to students behavior particularly. Because the students are special, the teachers also require certain techniques to handle the special classroom condition.

Thus, the result of the research may enrich teachers' knowledge in having more options and ideas to teach mental retardation students as well as being attentive to teachers' classroom management. Therefore, the writer decided to investigate the teaching strategies and classroom management techniques used by English teacher at SMP Inklusi TPA Jember. The writer wants to describe the strategies used by the teacher as well the classroom management techniques in teaching English subject for students with special needs. 


\section{LITERATURE REVIEW}

\section{Students with Special Needs}

Students with special needs are students with learning disability. The meaning of "need" is emphasized for educational needs. The children with special needs are children who need the appropriate education service because of their exceptional several categories of impairment which including of disability, namely physical, mental, emotional, sensory and neurological.

According Kauffman and Hallahan (in Delphie, 2006) Students with special needs who require more attention from the teachers are:

1. Learning disabilities or special learning disability students. Low-achieving children (underachiever) generally find in school, because they are generally not able to master a particular field of study prescribed by the teacher based on the applicable curriculum. There most of themthe possession of the lesson very well mrked with laceand IQ test sare under the normal average. Achievement of low achievementis generally caused by braindys function, dyslexia, orperceptual disability.

2. Attention deficit disorder with hyperactive students. Hyperactiveis not adisease buta symptom.Symptoms occur due to factors damage brain, anemotional disturbance, ahearing deficit, ormental retardation. It might happen hat a child has adisorderin-attention disorder with attention-deficit disorder with hyperactivity. Att he present time many medical circles refer to children hyperactive with term attention deficit disorder (ADHD). Abnormality indications in children hyperactiveare among other in-intense, hyper activity and impulsivity. Children hyperactive requirea service by providing with therapy pharmacological interventions combined with behaviortherapy (behavior modification).

3. Communication disorder or deafness students. Form of expression is different with students with hearing impairment of children with special needs the others. Thisis caused they never heard of oruse thesen sesears and mouth. Therefore they do not really know what they mean and with said by others. Communication dis order or deafnessis someone who is experiencinga lack orloss of hearing abilityas a whole or. It is caused malfunction of part or all of the sense of hearing.

4. Partially seeing and legally blind students. Children experiencing barriers to its development vision is different from other children with special needs, not only in terms of vision but also of other things. Learners who have little or seen at all, must study the surrounding environment by touching and feeling. To know the object's behavior in a way to hear the sound of the object to be achieved is the development of motor behavior. 
5. Autistic students. Syndrome Autismis a disorder caused by the existence of barriers to thein ability of language caused by brain damage. Children with autism generally experience abnormality in speech, in addition to impaired intellectualability and nerve function. This can beseen with the peculiarity of behavioran dinability to interact with the environment surrounding communities. Children symptoms with autism are not concerned with the environment, except the thing that she liked.

6. Physical disability students. Basically abnormalities on physical disability learners are grouped into two categories, namely cerebralab normality in the systemand the musculo skeletal system. Thelearners have a physical disorder, physical disability that impaired motor coordination, perception, and cognition to the specific nerve damage. Injury nerve is caused by alack of nerve cell grow thorsores on the central nervous system.

7. Multiple handicapped students. Freely interpreted that multiplehan dicappedare those who have developmental abnormalities include groups who have developmental neurologic barriers caused by one or two combination intelligence such as abnormalitiesin abilities, movement, language, orpersonal relationshipsin the community. They are grouped into multiplehan dicapped, among others, impairedand mentally retarded, cerebralpalsy, epilepsyorautism. Others claimthat multiplehan dicapped defined as abnormalities that interlocked liketuna with a totally blindand mentally retarded, mentally impaired with abnormalities that areorthopedist.

8. Giftedness and special talent students. Child's giftedness havean IQ score of 140 or moreas measured by the instrument cabinet Stanford have high creativity, leadership capabilities and abilityin the arts of drama, dance, and art. Otherwise it could mean a child gifted student swho have superior abilities in terms of intellectual, technical,a esthetic, social, physical, psychomotor, and psychosocial.

\section{Mental Retardation Students}

The most widely accepted definition of mental retardation is that provided by The America Association of Mental Retardation (AAMR)“ Mental retardation refers to substantial in present functioning. It is characterized by significantly subaverage intellectual functioning. Existing concurrently with related limitations in two or more of the following applicable adaptive skill areas: communication, self-care, home living, social skills, community use, self-direction, health and safety, functional academic, leisure and work. Mental retardation manifests before age 18. (AAMR Ad Hoc Committee on Terminology and Classification in Parsons et.el, 2001)" 
The diagnosis of mental retardation is based solely on an estimate of an individual's intellectual functioning or IQ score. Quite often, the score selected to define retardation varied from the school district. Mild, moderate, severe, profound classify is a term often using by America Association on Mental Deficiency (AAMB). In educators classify is known with term educable for mild category, trainable for moderate category, severely and profoundly for severe and profoundly.

\section{The Characteristic of Mental Retardation Students}

The disorder is characterized by a number of symptoms, one of which the inability intellectual and social. Mental retardation children are distinguished from the non retarded on the basic of intellectual functioning and adaptive behavior. Adaptive behavior refers to the amount of personal independence and social responsibility the person demonstratives at various stages throughout life.

Besides being intellectual functioning and adaptive behavior, mental retardation fails to acquire normal language skill. They often have problem when they want to say something. Mental retardation child talks are not clear, flat intonation and often repeating the words. Their composition of sentences is often upside down. For example: "I throw the rubbish" to "the rubbish throw I". Difficulties to understand the content or aim of the mental retardation child talks becomes increasingly, if they simplified the words into syllables. Moreover in children with severe degrees of mental retardation are often to simplify the sentences into syllables. Eg "I want to eat" to "at". The word "moon" and the word "month" often heart as the same sound and only the sound "O" (Rochyadi, 2005). The behavioral characteristic of mental retardation according to Payne \& Patton (1981) include Level 1 (mild), level 2 (moderate), level 3 (severe), level 4 (profound).

\section{Teaching Strategy for Mental Retardation Students}

The main goals often are to teach children with mental retardation basic educational skill. Here are some positive teaching strategies for interacting with students who have mental retardation (Omrod, 2000) :

1. Pace instructional slowly enough to ensure a high rate of success. When working with students who have mental retardation, we should through topic and assign new tasks slowly enough that the student experiences a high degree of success. Students with mental retardation typically have a long history of failure of at academic tasks; hence they need frequent success experiences to learn that they can succeed in school.

2. Explain tasks concretely, specifically, and completely. As noted earlier, students with mental retardation have difficulty filling in details correctly 
when instructions are ambiguous or incomplete. If we tell a student only to "take this absente to the principal's office," it may not occur to the classroom after completing the errand. Instead, we should provide concrete, specific, and complete instructions; for example, we might say, "go to the principal's office, give Mrs. Smith the absentee sheet, and come back here"

3. Provide considerable scaffolding to facilitate effective cognitive processing. Students with special needs often have little awareness of how to direct and regulate their own language. So, it is often helpful to provide extra guidance in terms of cognitive processing. For, instance, we help students focus their attention by using such phrase as "get ready, "look," or "listen". We can teach them a few simple, concrete memory strategies, such as repeating instructions to themselves or physically rearranging a group of items that they need to remember. We can also give them simple, structured study guides that quite specifically tell them what to focus on when they study.

4. Include vocational and general life skill in the curriculum. Most students with mental retardation join the adult work force rather than go on to higher education. Accordingly, an important part of any high school curriculum for students with mental retardation is training in general life and work skill. Because of student's limited ability to generalize what they have learned from one situation to another, it is especially important to teach life and work skills in realistic setting that closely resemble the situations in which students will find themselves once they leave school.

5. Encourage independence rather than dependence on the others. When we notice a student with special mental retardation being overly depended on other people, we should discourage such dependence as much as possible. If a student comes to the class without a pencil, we might ask the student to purchase one from the classroom supply cabinet, rather than simple hand out a pencil. And we might give specific instructions about what a student should do independently with any free time after assigned tasks are complete.

\section{Classroom Management Techniques}

Management Techniques are the way of teacher to take control of the classroom. Managing the class means managing the relationship with students and dealing with teacher-students behavior. The techniques are more emphasizing on the psychological aspects in teaching and learning. Therefore, if the relationship is running well between both sides, hopefully the students will be more involved and interested in learning without causing discipline problems.

According to Sarosdy, et.al (2006), there are seven techniques in managing the classroom, namely, a) show respect for students, b) clearly define the boundaries of behavior, c) behavior modification, d) professionalism, e) class 
techniques, f) teacher's role, g) know the students. In order to teach students with mental retardation, the teacher must consider the interaction between instruction as well as the level of handicapping condition. The consideration of mental retardation levels may lead the appropriate instruction and approaches. As stated by Taylor \& Sternberg (1989). The four levels as mentioned previously can be grouped into mild/moderate and severe/profound. It means, similar instructional approaches can be applied with students who are at the similar level of the group.

On the other hands, some opinions arise that there is another consideration of adaptive function. It covers intellectual scores, adaptive functioning scores from an adaptive behavior scale based on descriptions of known abilities provided by someone familiar with the person, and also the observations assessment examiner who is able to find out directly from the person what one can understand and communicate (Onyekuru \& Joyce, 2012).

\section{RESEARCH METHOD}

This research employed descriptive quantitative research in the scope of case study because the researcher would like to describe the phenomena of teacher's strategies in teaching English with special needs and the classroom management techniques used by the teacher in the classroom in a deeper investigation. The subject of this research was one English teacher of SMP Inklusi TPA Jember. This teacher taught at SMP Inklusi TPA Jember and taught mild mental retardation students. There was one teacher who was teaching mental retardation students in SMP Inklusi TPA Jember. The researcher took one teacher because he was the only English teacher who taught mild mental retardation. The teacher taught English subject every Saturday in a week.

In this research, the researcher took mild mental retardation students because the average IQ that they had was in range between 68-52 Bitnet scale. It means that they had higher IQ compared to other types of mental retardation based on the IQ. Meanwhile, other types of mental retardation students had less than 51 Bitnet scale.

In collecting the data, the researcher applied observation and interview as the techniques. The instruments were used to collect all the data that were necessary for the research. The researcher used non-participant observation because the writer observed the natural setting of teaching strategy used by teacher in teaching English without interacted directly in the teaching-learning process. Here, the researcher took in the back seat while writing some field notes and recording the activity in order to gain the necessary data.

The researcher conducted the observation three times. During observation, the researcher observed the factual situation of learning-process in the classroom 
such as: material presentation, teaching strategy used in classroom activity. The researcher also used a check list to get information needed.

In this session, the researcher interviewed one English teacher as the subject of the study. The researcher asked some questions related to the study and also cross-checked what had been obtained in the observation session for getting valid information from the English teacher. Furthermore, the interview was conducted by using Indonesian language as the second language of the teacher. The data then were analyzed by classifying, interpreting, tabulating, describing and drawing the conclusion.

\section{FINDINGS}

\section{Kinds of Teacher's Strategy for Students with Special Needs}

Based on the observation conducted on December 3rd, 10th, 17th, 2011 and some interviews, the researcher found that the teacher used three kinds of strategies to teach students with special needs. They were imitation and modeling strategies, demonstration strategy, and individual strategy. The teacher used those strategies to improve the students' ability in learning English.

The first was imitation and modeling strategies. This strategy was based on the repetition. The teacher asked the meaning of some vocabularies and modeled how to pronounce vocabularies. The teacher also asked the students to repeat vocabularies. The teacher drilled some vocabularies in group and individually. The lesson that theteacher taught to the students was only vocabulary. The student did not only imitate pronunciation of the teacher but also the teacher used "Talking Book" learn pad (The electric pad which produce spoken version based on vocabulary of picture).

The second was demonstration strategy. The teacher used "Talking Book" learn pad to show the situation of something. For example if the teacher taught the picture of the window, the pad would produce sound such as window which opens. The pad helped the teacher to give example of concrete thing to the students. On the other hand, the teacher became a model to demonstrate some vocabularies. He gave model by using gesture how to pronounce and remember the vocabulary easily. This was done by demonstrating the vocabulary of human body parts.

The third was active strategy. In this strategy the teacher included the students directly in teaching-learning process. The teacher asked some questions to students and the students answered the teacher's questions. To know students understanding, the teacher asked the students individually.

Based on the three kinds of the teaching strategies used by teacher, he used those kinds of strategies in different frequency in every meeting. The teacher applied two to three strategies in teaching students with special needseffectively in 
each meeting. The researcher described how the teacher applied the teaching strategies when the teacher did teaching-learning process.

In the first observation and the second observation, the teacher used three kinds of strategies. The strategies used were demonstration and imitation, modeling and active strategies. The teacher reviewed the previous lesson by asking the meaning of some vocabularies, such as milk, nail and window. The teacher used "Talking Book" learn pad to help the students how to pronounce well. In "Talking Book" learn pad the students saw the picture of some vocabularies and listened the pronunciation.

In the last observation, the researcher found that the teacher used imitation and modeling, demonstration, and active strategy. The teacher repeated some vocabularies to make understand the students. The teacher also became a model to be imitated by students. In the last observation the teacher included the students in learning process to make the students more active in class.

It was found that the teacher used three kinds of teaching strategy. They are imitation and modeling, demonstration, and active strategies. The mean score obtained by observation in imitation and modeling strategy was 48 . The mean score from checklist of observation was found that demonstration strategy was 43,75 . And the mean score for active strategy was 18,75 . Thus, it can be said that the most dominant strategy used by teacher in teaching English for students with special needs was imitation and modeling strategy.

\section{Teacher's Classroom Management Techniques}

According to Sarosdy, et.al (2006), there are some techniques listed, i.e. 1) show respect for students, 2) clearly define the boundaries of behavior, 3) behavior modification, 4) professionalism, 5) class techniques, 6) teacher's role and 7) know your students. Based on the data collection and data analysis, the techniques applied by the teacher in the classroom with mental retardation students encompasses

1. Showing respect for students, the teacher was showing his respect for students in the case of calling and addressing them with names, expressing grateful, listening as well as giving individual attention to students who need more attention at the time.

2. Showing professionalism, in term of managing his emotion by ignoring the bad attitude of the students by not taking it personally. But in another case, he still could not do the proper professionalism term as stated by the expert dealing with the exercises or assignments. It happened because of the condition of the classroom that made it impossible to do.

3. Class techniques, including doing eye contact, lowering body position when talking personally, showing the authority, use kita'we' to show togetherness 
4. Teacher's role, including friendly attitude, showthe power to control not to get angry or dominating

5. Knowing the students, by recognizing the students' diversity, applying individual approach to surprise them.

\section{DISCUSSION}

The research finding showed the kinds of strategies used by the teacher, the most dominant strategy, and the teacher's reasons used the most dominant strategy. The teacher used three kinds of strategies. They were imitation and modeling strategy, demonstration strategy, and active strategy. Teaching strategy is used in helping the students to reach the objective that the teacher prepares in the planning phase of instructional. Brown (1994) defines strategies as specific methods of approaching a problem or task, modes of operation for achieving a particular end, planned design for controlling and manipulating certain information.

The most dominant strategy used by teacher was imitation and modeling strategy. That strategy helped students with special needs to improve English skill. According to Countright and Courtright in Mercer \& Mercer (1989) modeling involved acquiring an abstract language rule without giving an immediate response to the stimulus. Mimicry distinguishes between modeling and imitative behaviour. Many studies have documented infant's abilities to selectively imitate a model's behavior. The teacher's reasons used that strategy was to make students understand directly the topic of the lesson and to stimulate the mentally retarded remember the vocabulary or topic easily. According to Omrod (2000) some positive teaching strategies for interacting with students who have mental retardation, that is measuring the step of instructional slowly enough to ensure a high rate of success. It means that when working with students who had mental retardation, we should teach the topic and assign new tasks slowly enough that the student experienced a high degree of success. Other positive strategy was explaining tasks concretely, specifically, and completely. Students with mental retardation had difficulty filling in details correctly when instructions were ambiguous or incomplete.

According to Sarosdy, et.al (2006), there are some techniques listed, i.e. 1) show respect for students, 2) clearly define the boundaries of behavior, 3) behavior modification, 4) professionalism, 5) class techniques, 6) teacher's role and 7) know the students. There were only 5 techniques found applied by the teacher in teaching students with mental retardation. Through the observations in the classroom, there were many things that supported the data to explain the description of the techniques in detail.

The first technique was the teacher showed his respect for his students. Respect here means that he was making manner to his students without showing 
that he disregards. Particularly, the teacher was showing his respect for students in the case of calling and addressing them with names. For example, "Nina, apakabar?". He addressed by the student's nickname with slower motion and soft voice as he tried to emphasize on the intention. He also expressed his grateful by saying "Terimakasih" (Thank you) for students who helped him doing something. This act was also the part of showing respect and appreciation. Respect also means listen to each other. When a teacher listens to the students, he/she will receive the similar act that make the students less annoying and be motivated in working (Fleury, 2019). The teacher also listened as well as gave individual attention to students who need more attention at the time. In contradiction with a previous research that female teachers are more positive and have good tolerance than male teachers (Fakolade, et.al, 2009), the finding shows that male teachers can also have positive attitude in the classroom.

The second technique was showing professionalism. The technique was found in the classroom and applied by the teacher in teaching English to the mental retardation students. Although this thing quite difficult, the teacher attempted to apply the technique to the special students. He succeeded to control and managed the emotion in controlling the extraordinary attitude of the students. The important thing is he did not take it personal. Although, it was not easy to do, he showed the attitude of patience. This technique is applied as the result of the educational background and teaching experience of the teacher as mentioned by Supriyanto (2019). This teacher includes as a professional teacher because he has more favorable attitude toward his students. As explained by Fakolade, (2009), a professional teacher with more knowledge and experience has favorable attitude to inclusive students. However this professionalism was only for the direct activities in the classroom and cannot be applied in giving further assignments because of the limitation of the condition.

The third was class techniques. The techniques specifically referred to more physical activities in the classroom including doing eye contact, lowering body position when talking personally, showing the authority, use kita' we' to show togetherness. Having an eye contact more specifically and more personally is important to apply in teaching special students. And this was done by the teacher more intense because the students need it more. When the teacher was trying to convince, warn, and teach the attitude, he lowered the body position as the same as his students. In fact, children with autism and emotional disorder require intervention of social skill training to improve their communication skill (Wills-Jackson, 2018). Therefore, it caused effectiveness in having more concerned communication.

The fourth was the teacher's role. The role means here is about the specific role of the teacher in the classroom such as the friendly attitude and the power 
control in a positive performance. In his performance, the teacher had his friendly attitude shared to all students by smiling, giving attention, and showing friendly gestures. He could perform his friendly attitude to the students even though not to the whole areas of the class. Moreover, he also could manage his power to control the whole class even though he had some difficulties to it, such as, handling the noisy students and disciplined them when they made mistakes. In this kind of interaction, the social interaction with those special students must be increased significantly because it can promote more positive attitude (Raty, et.al, 2016).

The fifth was know the students. In this case, the teacher must understand the situation and the condition happened in the classroom. It is important for teachers to know more about the students not only about their academic performance but also their personal background or problems. It is because commonly students' personal problems can affect their academic performance. The problems can be derived from family or environment. According to Jacob \& Ryan (2018), life outside of school affected students' academic performance at school. It can be poverty, child abuse, domestic violence, etc. that can cause the trauma. Therefore, it is important for the teacher to recognize the students' diversity and applying individual approach to surprise them. Knowing the students' diversity can assist to figure out what the individual approach applied to the students.

\section{CONCLUSION}

Teaching students with mental retardation requires particular ability including the strategies and classroom management techniques. The research finally revealed the strategies dominantly used by the teacher in teaching English at SMP Inklusi TPA Jember, namely, imitation and modeling strategy. There were 5 techniques applied by the teacher including showing respect for students, showing professionalism, applying class techniques, applying positive attitude of teacher's role and knowing the students. 


\section{REFERENCES}

Amalia, L. (2014). Teaching vocabulary to students with mental retardation in the seventh grade of SMPLB Negeri Jepara in the academic year 2013/2014. Undergraduate Thesis. Kudus: Muria Kudus University.

Artiyah, A. (2016). A study on EFL teaching and learning of students with mental retardation (MR) in the center of the child rehabilitation (a study at SMALB-C YPAC Semarang). Undergraduate (S1) thesis, UIN Walisongo. http://eprints.walisongo.ac.id/id/eprint/6173

Barbra, M \& Joyline, N. (2014). The Inclusion of Children with Mental Disabilities: A Teacher's Perspective. International Journal of Humanities Social Sciences and Education (IJHSSE). 1 (1). 65-75.

Brown, H.D.(1994). Teaching by Principle: An Interactive Approach to Pedagogy (1st Edition). New York: Addison Wesley Longman, Inc.

Delphie, B. (2006). Pembelajarananakberkebutuhankhususdalam setting inklusi. Bandung: PT RefikaAditama.

Fakolade, O.A, Adeniyi, S.O \& Tella, A. 2009. Attitude of teachers towards the inclusion of special needs children in general education classroom: the case of teachers in some selected schools in Nigeria. International Electronic Journal of Elementary Education .1 (3).

Fleury, K. (2019). East Otago High School.Respect: resilience, excellence, support, pride, engagement, creativity, teamwork. Retrieved February 5, 2020.https://eohs.school.nz/2019/03/importance-of-respect/

Hsu, Hui-Ching and Lin, Chien-Hui.(2006). The Effects of Total Physical Response on English Functional Vocabulary learning for Resource Classroom Students in the Elementary School. (http://www.enews.sjses.chc.edu.au/TotalPhysicalRespons/vocabulary.htm 1)

Jacob, B.A \& Ryan, J. (2018). Brookings. How life outside of a school affects student performance in school Brookings. https://www.brookings.edu/research/how-life-outside-of-a-school-affectsstudent-performance-in-school/

Mercer, C. D and Mercer, A. R. (1989). Teaching students with learning problem (3rd edition). Newyork: MacMillan Publishing Company.

Gnanaguruvammal. (2010). Knowledge and attitude towards mental illness among teachers in the selected schools in sivagangai district, Tamilnadu. Masters thesis, Matha College of Nursing, Manamadurai. http://repositorytnmgrmu.ac.in/id/eprint/5479

Omrod, J. E. (2004). Educational psychology. Developing Learners (3rd Edition). New Jersey: Prentice Hall Inc Pearson Education.

Onyekuru, B.U.D \&Njoku, J. (2012).Classroom management of mental retardation. International Journal of Learning and Development.2 (5).105111.

Parsons, R. D, Hinson, S.L and Brown, D. S. (2001).Educational psychology.A practitioner researcher model of teaching. USA: Wadsworth, a division of Thomson Leraning Inc 
Raty, L.M.O, Kontu. E.K, \& Pirttimaa. R.A. (2016). Teaching children with intellectual disabilities: Analysis of research-based recommendations. Journal of Education and Learning. 5 (2). 318-336.

Resti, A.S. (2017). Teaching English to Mental Retardation Students at SMPLB Negeri Pembina Samarinda in Academic Year 2017/2018. Undergraduate Thesis. Education and Teacher Training Faculty, State Institute of Islamic Studies Samarinda.

Rochyadi, E. (2005). Pengembangan Program Pembelajaran Individual bagi Anak Tunagrahita. Jakarta: Depatemen Pendidikan National.

Santrock, J. W. (2008). Educational Psychology (3 ${ }^{\text {rd }}$ edition). New York: McGraw-Hill.

Supriyanto, D. (2019). Teachers' Attitudes Towards Inclusive Education: A Literature Review. Indonesian Journal of Disability Studies (IJDS). 6 (1). 29-37.

Sarosdy, Bencze, Poor\&Vadnay. (2006). Apllied Linguistic 1 (for BA Students in English). Bolcsesz: Konzorcium

Taylor, R.L \& Sternberg, L. (1989).Teaching students with mental retardation. Pp 124-149. Ed Exceptional Children. New York: Springer-Verlag New York Inc. DOI https://doi.org/10.1007/978-1-4612-3602-3_6

Wills-Jackson, C. (2018). Implementing Gamepla Implementing Gameplay Skills t y Skills to Increase Eye Contact and e Contact and Communication for Students with Emotional Behavioral Disorder and Comorbid Disabilities. STARS Electronic Theses and Dissertasions, 2004-2019. https://stars.library.ucf.edu/etd/5979 